\section{El ocio cotidiano}

David Jolly Profesor, Pontificia Universidad Católica de Valparaíso

Las situaciones cotidianas observadas y dibujadas por un arquitecto se configuran como la base de todo proyecto. En el caso de los momentos de pasatiempo se miden las posturas que recogen las diferentes experiencias. Es así como el cuerpo recoge en cada parte de sí mismo la distensión del tiempo que no es útil.

El ocio aparece primeramente opuesto al negocio. El negocio es una acción que persigue un fin conocido, se puede prever su resultado. Conoce o tiene un fin predeterminado, esta dirección sustenta, justifica y permite.

Ahora existe también una actividad que podemos nombrar como el pasatiempo. Podemos conjeturar que la condición humana tiende a disponer de sí misma, tiende a culminar en esta disponibilidad en lo que no está obligado. Ganarse la vida es una condición ineludible, es estar obligado, es el negocio. Este negocio tiene como contrapartida el pasatiempo, que es disponer del tiempo en una actividad que divierte o distrae. Una característica del pasatiempo es que no involucra a quien lo realiza, no le implica un concernimiento, por esto produce un descanso aunque se esté ante algo consistente. Se está ante una construcción pasivamente desde fuera, a una distancia.

Vecino a esta realidad tenemos el juego, que es el tiempo de un fin en sí mismo y que es un extremo del ocio. Sin embargo me quiero dirigir a otra zona del ocio donde queda más expuesta su fragilidad.

La primera característica que le puedo suponer al ocio es que involucra enteramente a quien se hace parte de él, ya que se trata de una actividad del espíritu que se sabe como tal y debe ser sostenida. Esto es porque se sitúa ante lo que no se tiene por conocido ni previsible, un modo de nombrarlo es la contemplación. Ahora en cuanto nos ha tocado vivir la experiencia del ocio como contemplación caemos en la cuenta que es muy exigente de algunas condiciones para ser tal. Esto puede ser explicado en un nuevo distingo ya que el ocio no es la vagancia que es errar sin rumbo o, lo que es lo mismo, divagar.

De este modo aparece que no cualquiera accede al ocio, no está disponible para cualquiera, pide algunos requisitos. El pasatiempo está disponible si no para todos, para muchos, porque es un descanso sin concernimiento. El divagar obtiene su justificación al ser un pasatiempo o es un error.

El ocio se abre para quien construye una extensión donde éste es posible, llamémosla de un modo elemental un campo. Y precisando la realidad de un campo digamos que es donde se da la contemplación. Así el ocio es el polo opuesto al negocio, ya que no conoce su término y corre un riesgo al abrirse a una posible realidad.

Para algunos arquitectos nos ha sido dado un modo del ocio que se configura como campo en el dibujo. Este es un campo porque construye un modo elemental de la abstracción, quien sale a dibujar lo hace de cuerpo presente ante y dentro de lo que lo detiene. Se sitúa en un campo creativo donde dibuja extendiéndose ante lo que sus ojos miran, el que mira cuando repara en algo puede decir que ha visto. Este paso de mirar a ver es con la palabra. Lo que se ve tiene una parte que se dice con los trazos y una parte que la ven las palabras. Esta detención sin propósito previo reúne sobre el papel al menos dos dimensiones que aporta quien dibuja, lo que viene a sostener la proposición de campo. El que contempla fijando lo que ve en el dibujo lo hace con su sensibilidad para percibir aquello que se hace presente en ese instante; de la multiplicidad de hechos que ocurren en una detención, el que dibuja decide sensiblemente aquello que lo ha detenido, es una abstracción.

La segunda dimensión que viene a configurar nuestro campo que no es solo sensible, ya que en el presente el mundo viene a ser a cada instante simultá-

\section{Everyday Leisure}

David Jolly Professor, Pontificia Universidad Católica de Valparaíso

The daily situations observed and drawn by an architect are configured as a base of every project. In the case of the hobby the positions that collect the different experiences are measured. In this way the body collects the relaxation of underutilized time in each part of itself.

Leisure appears to be in direct opposition to business. Business is an action that pursues a known end, one can for see its result. It knows or has a predetermined aim, this direction sustains, justifies and allows.

Now an activity exists that we call the hobby. Here, we can conjecture that the human condition tends to become available to itself. It culminates in this availability to which it is not obligated. Earning a living is an unavoidable condition. It is to be obligated. It is business. This business has the hobby as its counterpart that is to designate time to an activity that entertains or distracts. One characteristic of the hobby is that it doesn't involve the person who carries it out. It does not imply involvement, thus producing relaxation despite facing something consistent. They face a passive structure from the outside, at a distance.

Akin to this reality we have the game in which time itself is the aim and lies at the extreme of leisure. However, I would like to address another area of leisure where its fragility is more exposed. The first characteristic of that can be supposed is that it completely involves the person taking part. It consists of an activity of the spirit that is known as such and must be sustained. This is because it is situated in that which is neither known nor foreseeable. One way of naming it is contemplation.

Now, as we live the experience of leisure as contemplation we fall into the account that it is extremely demanding of certain conditions to be as such. This could be explained in a new recognition that leisure is not an idleness that wanders without aim nor a digression.

In this manner it appears that not just anyone can access leisure. It is not available for just anyone; it has requirements. The hobby is available for many, if not for everyone, because it is a rest without involvement. The digression obtains its justification by being a hobby or is becomes just an error.

Leisure is open to those who build an extension where possible, lets call it an elemental mode, a field. And specifying the reality of a field where contemplation occurs. In this way leisure is the polar opposite of business in that it the end is unknown and runs the risk of opening onto a possible reality.

For some architects, we have been given a method of leisure configured in the field of drawing. This is an area that constructs an elemental method of abstraction. Whoever draws, draws with their present body on the outside and that which restricts them on the inside. It is situated in a creative field where drawing extends before the eyes that see. The person that looks when he focuses on something can say that he has seen. This step of seeing is with the word. That which is seen has a part seen with lines and another seen with words.

This pause without foreseen intention meets at least two dimensions on paper that support the drawer and sustain the drawing. The contemplator fixes what he sees in the drawing with his sensibility to perceive what is present in the instant; from the multiplicity of facts occurring in this pause, what he draws decides that which remains, an abstraction.

The second dimension configuring our field is not only sensitive as the present world comes to be in each instant simultaneously in the memory 


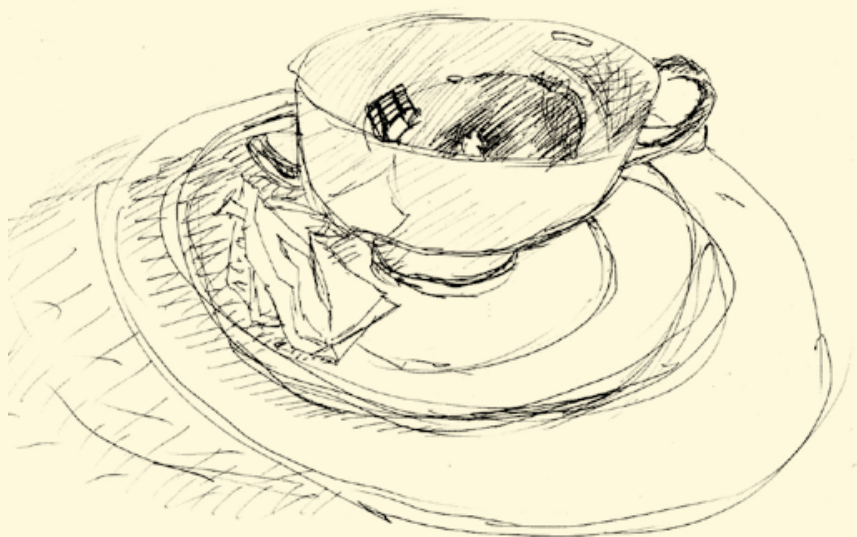

01 En una taza, el brillo incluyente deja dentro una cantidad de figuras y luces. La única reconocible es la ventana y su contraluz; los otros brillos y sombras son un trazado abstracto que no deja reconocer su origen. 01 In a glass, the shine creates a guantitiy of figures and lights, the only recognizable element is the window and its backlight. The other lights and shades are an abstract tracing that leaves the origin undiscernible.

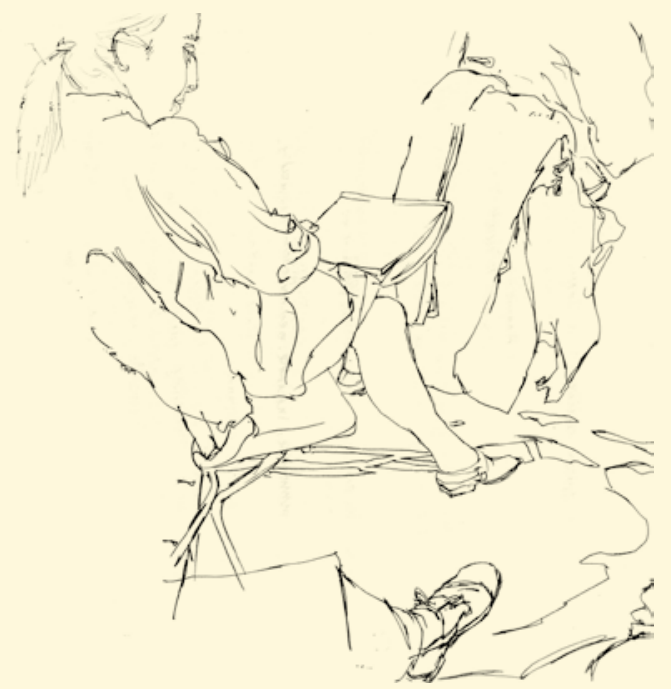

04 Asistir a clases, el cuerpo en reposo dispuesto a oír y registrar. Estar sentado es la posibilidad de apoyar un solo pie en el suelo. Los pies dejan de sostener el peso del cuerpo y el oído y la mirada sustentan la atención. 04 To attend classes, the body in repose, available to hear and register. To be seated is the possibility to place only one foot on the ground. The feet stop sustaining body weight and the heard and seen sustain the attention.

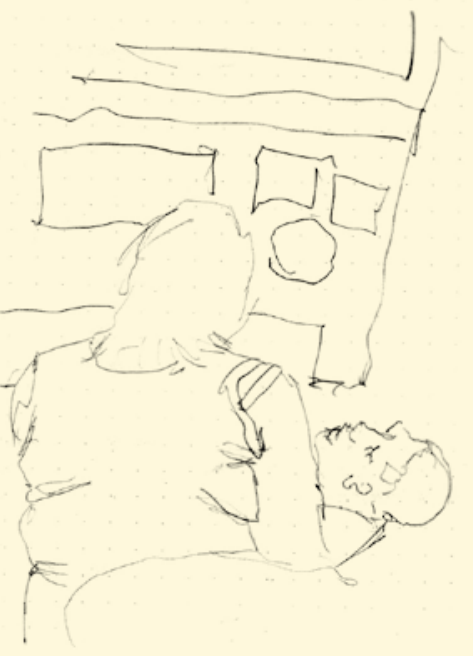

02 En el bus un niño duerme en los brazos de su madre. El gesto, la actitud y el cuerpo suplen el espacio. 02 On the bus, a boy sleens in his mother's arms. The gesture, the attitude and the body make up the space.

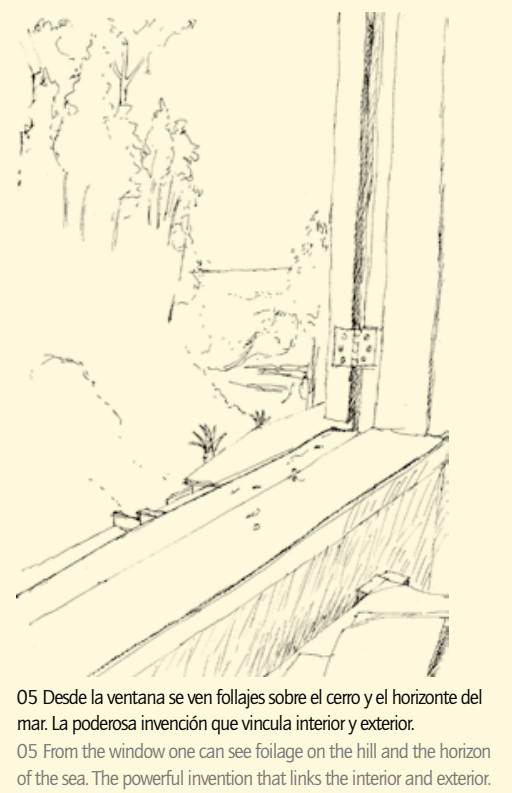

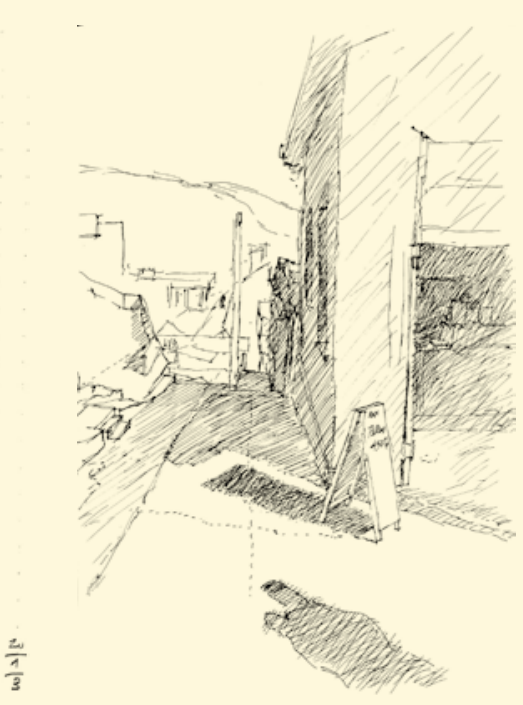

03 En el cerro Barón de Valparaíso una mañana de sol la acera se presenta como equivalente al interior de la panadería. 03 On the cerro Barón in Valparaíso a sunny moming, the sidewalk is presented as an equivalent to the interior of a baken.

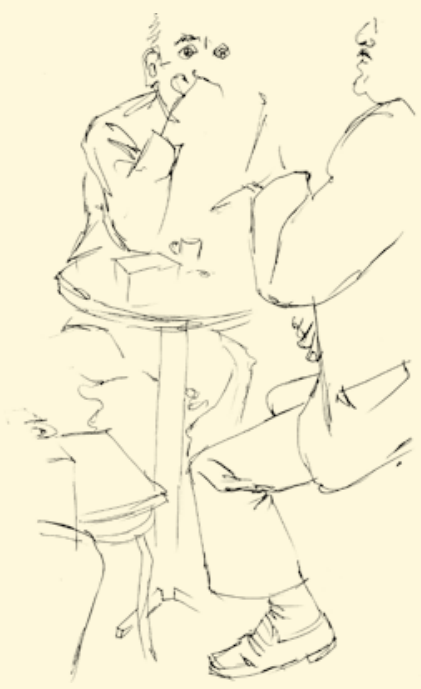

06 La pequeña mesa al brazo del café, lo que fija es la mirada. El cuerpo detenido reposa erguido para hablar. 06 The small table in the cafe is what fixes the gaze The detained body rests lifted to speak. neamente en la memoria de quien contempla. Y así como el dibujo abstrae de la abundancia de la extensión algunas aristas y deja otras, en la palabra se hace presente aquella construcción de mundo que llevamos en la memoria y que se presenta en la mente de quien contempla y que es del caso fijar en el dibujo.

Este modo del ocio en un campo configurado por el dibujo y la palabra lo ejercemos los arquitectos en la extensión del mundo en la que habitamos; contemplamos el mundo en cuanto éste se erige en habitación del hombre. Intuimos que la contemplación es una alta manifestación del ocio entendido en los términos que hemos expuesto, ya que se abre a la posibilidad que sólo el hombre libre puede ejercer.

Ahora este modo de la contemplación no quiere decir que se constituya en una actividad inútil. Por el contrario, el carnet de croquis es el fondo contemplativo que cada arquitecto sostiene y lleva consigo en una abundancia primera, el que sin tener un fin predeterminado es sin embargo su conciencia especulativa. Lo observado le garantiza no resultados de antemano, sino que cuenta con un-nomás-atrás que es el origen de su autoridad. El arquitecto está concernido y conoce como experiencia a través del dibujo el acto de habitar. Cómo los hombres habitan hoy, cómo se da a ver la extensión vuelta espacio, conteniendo toda la tradición, que es esa invención original que nos sostiene en el presente.

Acompañamos este breve texto con algunos croquis que dan cuenta del ser de esta posibilidad contemplativa, anterior a todo propósito que es lo propio del ocio. ARQ of the contemplator. In this way the drawing abstracts from the abundance of the extension, choosing details and leaving others. In saying that the construction of the world is made present that we carry in our memory and is presented in the mind of the contemplator and is the one fixing on the drawing.

This manner of leisure in the field configured by the drawing and the world we architects exercise in the extension of the world we inhabit; we contemplate the world in how it is erected in the habitation of man. We sense that contemplation is a high manifestation of leisure understood in the terms we have exposed and are opened to the possibility that only the free man can exercise.

Now this way of contemplation does not mean to say that it is built on a useless activity. On the contrary, the identity of the sketch is the contemplative heart that each architect sustains and carries with him in abundance. To be without a predetermined aim is his speculative conscience. The observed guarantees no upfront results besides the base that is the origin of its authority. The architect is concerned and knows experience the act of habitation through the drawing. How men inhabit today, how this extension has become space, contains all the tradition that is original invention that sustains us in the present. We accompany this brief text with some sketches that give account to this contemplative possibility, previous to the principles that make up leisure. ARQ 